\title{
Effects of diffusion drying schedules on gas and liquid permeability in Paulownia fortunei wood
}

\author{
Efectos de los programas de secado de difusión sobre la permeabilidad del gas \\ y del líquido en madera de Paulownia fortunei
}

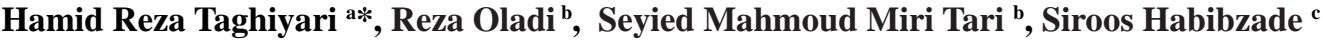

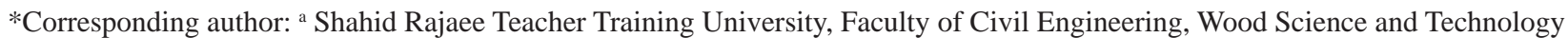 \\ Department, Lavizan, Shabanloo St., Tehran, Iran, Cellphone: (+ 98) 930-2005235, fax: (+ 98-21) 22970021, \\ htaghiyari@srttu.edu htaghiyari@yahoo.com \\ ${ }^{\mathrm{b}}$ University of Tehran, Wood and Paper Science and Technology Department, Karaj, Iran. \\ ${ }^{c}$ Gorgan University of Agricultural Sciences and Natural Resources, Wood and Paper Engineering Department, Gorgan, Iran.
}

\begin{abstract}
SUMMARY
As to the importance of permeability in the preservation process of solid woods, the effects of diffusion drying schedule with three different initial moisture contents (MC) on fluid flow in the sapwood and heartwood of paulownia wood (Paulownia fortunei) were studied here. Boards with initial MCs of $113 \%$ (D-1), $75.5 \%$ (D-2) and $53.5 \%$ (D-3) were dried to the final moisture content of $8 \pm$ $2 \%$. Results showed a significant difference in the specific gas and liquid permeability of paulownia wood dried with these different initial MCs. Although gas permeability of sapwood and heartwood specimens was significantly different, no significant difference was seen in liquid permeability between these two parts. D-2 and D-1 showed the highest specific gas and liquid permeability, respectively. It was therefore concluded that the initial MC has a significant effect on the gas and liquid permeability of paulownia boards dried under diffusion schedule with different MCs. Furthermore, the presence of tyloses plays a more important role in permeability than vessel size and frequency by forming an impermeable barrier, resulting in a significant decrease in gas and liquid permeability in paulownia wood.
\end{abstract}

Key words: diffusion, drying schedule, fluid flow, gas permeability, kiln drying, liquid permeability.

\section{RESUMEN}

En cuanto a la importancia de la permeabilidad en el proceso de preservación de maderas macizas, se estudiaron los efectos del programa de secado de difusión con tres diferentes contenidos de humedad (MC) iniciales en el flujo de fluido en la albura y el duramen de la madera de paulonia (Paulownia fortunei). Los tableros con MC iniciales de 113 \% (D-1), 75,5 \% (D-2) y 53,5 \% (D-3) fueron secados al contenido de humedad final de $8 \pm 2 \%$. Los resultados mostraron una diferencia significativa en la permeabilidad específica del gas y del líquido de madera de paulonia secada con estos diferentes MC iniciales. Aunque la permeabilidad al gas de la albura y duramen fue significativamente diferente, no se observó ninguna diferencia significativa en la permeabilidad a los líquidos entre estas dos partes. D-2 y D-1 mostraron la mayor permeabilidad al gas y a los líquidos, respectivamente. Por tanto, se concluyó que el MC inicial de paulonia tiene un efecto significativo sobre la permeabilidad al gas y al líquido de la madera secada con programas de difusión con diferentes MC. Además, la presencia de tilosis juega un papel más importante en la permeabilidad que el tamaño y la frecuencia de los vasos mediante la formación de una barrera impermeable, lo que resulta en una disminución significativa en la permeabilidad de gas y líquido en madera de paulonia.

Palabras clave: difusión, programa de secado, flujo de fluido, permeabilidad de gas, secado en horno, permeabilidad de líquido.

\section{INTRODUCTION}

Natural regeneration of trees (Ruprecht et al. 2012) is not enough for the increasing need of the wood industry; plantation of fast-growing species is therefore wide-spreading in city suburbs and rural areas in Iran. Paulownia is one of the fast-growing species that have been worked on from different aspects. As to the formation of tyloses in paulownia wood affecting its porous structure, its behaviors towards the preservation process, or drying schedules, are rather different from similar solid woods with nearly the same density; in this connection, it is to be noted that any change in drying duration and techniques significantly affects the properties of wood as a biological porous material (Mosqueda et al. 2013, Chaiyo and Rattanadecho 2013); and moreover, wood has a thermo-hygromechanical behavior because its deformation properties depend on the combined action of temperature, relative humidity, and mechanical load variations (Figueroa et al. 2012). The need to dry wood as quickly as possible, while avoiding the development of defects in the dried wood, has prompted researchers to develop wood drying schedules 
in order to achieve the desirable objectives (Korkut and Guller 2007). These programs regulate the kiln temperature and relative humidity $(\mathrm{RH})$ to finally achieve a suitable drying rate with which the woods are dried as rapidly as possible, without major drying defects. In some wood drying research, only the experimental data are presented; in general, however, a mathematical model is used (Babiak 2007, da Silva et al. 2011).

Drying schedules were reported to affect solid woods in three ways: the direct effect of moisture loss on physical and mechanical properties; the internal drying strain and stresses as well as occurrence of checks and cracks; and the direct influence of temperature on wood components (Thiam et al. 2002). Drying schedules at high temperatures were also reported to decrease mechanical properties and increase drying defects (Oltean et al. 2007). In this connection, many studies have been carried out on Iranian domestic species to both accelerate the wood drying process and decrease drying defects as low as possible (Ashouri and Ebrahimi 1999, Rafiei and Ebrahimi 2007, Shahverdi et al. 2012a); however, little attention was paid to fast-growing planted species, like paulownia. A highly significant correlation was reported between specific gas permeability and liquid permeability in paulownia wood, indicating the rapidness with which free water can transfer from inner parts to the surface layers to dry (Ghorbani et al. 2012). However, little or no study has so far been carried out on the effects of different wood drying schedules on fluid flow in paulownia wood. Gas and liquid permeability has significant effects on applications and processing techniques of wood (Taghiyari 2013). Wood preservation is closely related to the flow of liquid fluids into the wood structure. Furthermore, wood drying is significantly correlated to both liquid permeability in wood (when MC is above the fiber saturation point) and gas permeability in wood (when $\mathrm{MC}$ is below fiber saturation point). The present study was therefore conducted to investigate the effects of three different diffusion wood drying schedules on gas and liquid permeability in paulownia wood, as two important indexes of fluid flow in wood that affect its final application properties. The diffusive character of moisture movement in wood has been studied as schedules based on diffusion (Malmquist 1991, Danvind and Ekevad 2006, da Silva et al. 2011). In diffusion drying schedules, the initial moisture contents are different; however, the drying conditions and temperatures, as well as final moisture content, are all the same (tables $1-3$ ). In this connection, it is hypothesized that higher initial MC would cause higher severity in drying that in turn would lead to a significant difference in gas and liquid permeability in comparison with those schedules having lower initial MCs. Density is also one of the key factors in wood drying; however, in the present study, boards of the same logs were dried under different drying schedules; otherwise stated, density was not changed in any of the schedules. Therefore, the focus of our attention was on other structural factors such as vessel properties, and formation of tyloses. Furthermore, since vessels are the main route through which fluids pass in hardwoods, and the permeability of wood is significantly influenced by their anatomical features (Kurjatko et al. 2006), some vessel properties were also measured; the vessel properties included average vessel lumen area (AVLA), the percentage of vessel lumen area (PVLA), and vessel frequency (VF).

\section{METHODS}

Specimen procurement. Boards with a commercial nominal thickness of $50 \mathrm{~mm}$, and length and width of about 150 and $10 \mathrm{~cm}$, respectively, were cut from four freshlycultivated paulownia trees. The 15-year-old trees were grown in a forest close to Gorgan province, located in the Northern region of Iran. Density of specimens was 0.316 and $0.303 \mathrm{~g} \mathrm{~cm}^{-3}$ for heartwood and sapwood, respectively. Cross-sections of the boards were brushed with paint, immediately after the boards were cut. A semi-automatic conventional kiln, with one cubic meter capacity, was used to dry the boards (figure 1). The kiln stack was $60 \mathrm{~cm}$ wide; $2 \times 2 \mathrm{~cm}^{2}$ stickers from the same species were used between the boards. Air movement speed was set at about 2 $\mathrm{m} \mathrm{s}^{-1}$ provided by internal fans; air was horizontally circulated in the kiln. Four control samples were set among the boards to monitor the moisture reduction trend over time and in accordance with the drying schedules.

Kiln drying schedules. Three different initial moisture contents (MC) of $113 \pm 3 \%$ (D-1), $75.5 \pm 4 \%$ (D-2) and $53.5 \pm 3 \%$ (D-3) were chosen for the wood stacks (tables 1,2 and 3, respectively). Drying schedules were set based on the initial MCs of the stacks; the drying procedure continued till the MC reached the final target MC of $8 \pm$ $2 \%$. Control samples were weighed at least once a day to monitor the moisture content of the stack. The stack MC was then calculated and the steps of the drying schedule changed based on the average MC of the wettest half of the control samples (Simpson 1991).

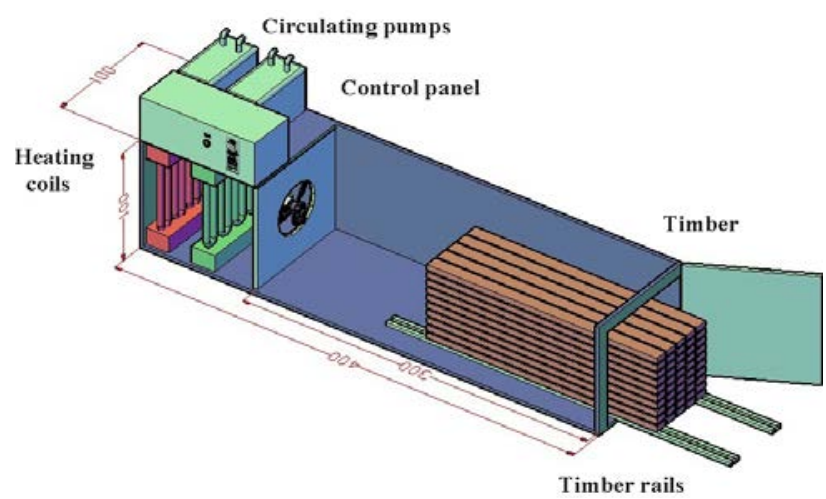

Figure 1. Schematic diagram of the semi-automatic conventional kiln. Diagrama esquemático del horno convencional semiautomático. 
Table 1. D-1 kiln drying schedule for $P$. fortunei lumber with $5 \mathrm{~cm}$ thickness (initial moisture content of $113 \%$ ).

Programa de secado en horno D-1 para la madera $P$. fortunei con $5 \mathrm{~cm}$ de espesor (contenido inicial de humedad de $113 \%$ ).

\begin{tabular}{cccccc}
\hline $\begin{array}{c}\text { Moisture content } \\
(\%)\end{array}$ & $\begin{array}{c}\text { Dry bulb } \\
\text { temperature } \\
\left({ }^{\circ} \mathrm{C}\right)\end{array}$ & $\begin{array}{c}\text { Wet bulb } \\
\text { temperature } \\
\left({ }^{\circ} \mathrm{C}\right)\end{array}$ & $\begin{array}{c}\text { Wet bulb } \\
\text { temperature } \\
\text { depression }\left({ }^{\circ} \mathrm{C}\right)\end{array}$ & $\begin{array}{c}\text { Relative humidity } \\
(\%)\end{array}$ & $\begin{array}{c}\text { Equilibrium } \\
\text { moisture } \\
\text { content }(\%)\end{array}$ \\
\hline$>65$ & 70 & 59 & 11 & 60 & 11.0 \\
60 & 71 & 59 & 12 & 60 & 11.0 \\
55 & 71 & 59 & 12 & 60 & 11.0 \\
50 & 71 & 59 & 12 & 60 & 11.0 \\
45 & 72 & 59 & 13 & 55 & 10.1 \\
30 & 72 & 59 & 13 & 55 & 10.1 \\
25 & 73 & 59 & 14 & 54 & 9.8 \\
20 & 73 & 59 & 14 & 54 & 9.8 \\
15 & 76 & 59 & 17 & 49 & 9.0 \\
$8 \pm 2$ & 76 & 59 & 17 & 49 & 9.0 \\
\hline
\end{tabular}

Table 2. D-2 kiln drying schedule for $P$. fortunei lumber with $5 \mathrm{~cm}$ thickness (initial moisture content of $75.5 \%$ ).

Programa de secado en horno D-2 para la madera P. fortunei con $5 \mathrm{~cm}$ de espesor (contenido inicial de humedad de 75,5 \%).

\begin{tabular}{cccccc}
\hline $\begin{array}{c}\text { Moisture content } \\
(\%)\end{array}$ & $\begin{array}{c}\text { Dry bulb } \\
\text { temperature } \\
\left({ }^{\circ} \mathrm{C}\right)\end{array}$ & $\begin{array}{c}\text { Wet bulb } \\
\text { temperature } \\
\left({ }^{\circ} \mathrm{C}\right)\end{array}$ & $\begin{array}{c}\text { Wet bulb } \\
\text { temperature } \\
\text { depression }\left({ }^{\circ} \mathrm{C}\right)\end{array}$ & $\begin{array}{c}\text { Relative humidity } \\
(\%)\end{array}$ & $\begin{array}{c}\text { Equilibrium } \\
\text { moisture } \\
\text { content }(\%)\end{array}$ \\
\hline 75 & 70 & 59 & 11 & 60 & 11.0 \\
60 & 71 & 59 & 12 & 60 & 11.0 \\
55 & 71 & 59 & 12 & 60 & 11.0 \\
50 & 71 & 59 & 12 & 60 & 11.0 \\
45 & 72 & 59 & 13 & 55 & 10.1 \\
30 & 72 & 59 & 13 & 55 & 10.1 \\
25 & 73 & 59 & 14 & 54 & 9.8 \\
20 & 73 & 59 & 14 & 54 & 9.8 \\
15 & 76 & 59 & 17 & 49 & 9.0 \\
$8 \pm 2$ & 76 & 59 & 17 & 49 & 9.0 \\
\hline
\end{tabular}

Table 3. D-3 Kiln Drying Schedule for $P$. fortunei Lumber with $5 \mathrm{~cm}$ Thickness (initial moisture content of $53.5 \%$ ). Programa de secado en horno D-3 para la madera P. fortunei con $5 \mathrm{~cm}$ de espesor (contenido inicial de humedad de 53,5 \%).

\begin{tabular}{cccccc}
\hline $\begin{array}{c}\text { Moisture content } \\
(\%)\end{array}$ & $\begin{array}{c}\text { Dry bulb } \\
\text { temperature } \\
\left({ }^{\circ} \mathrm{C}\right)\end{array}$ & $\begin{array}{c}\text { Wet bulb } \\
\text { temperature } \\
\left({ }^{\circ} \mathrm{C}\right)\end{array}$ & $\begin{array}{c}\text { Wet bulb } \\
\text { temperature } \\
\text { depression }\left({ }^{\circ} \mathrm{C}\right)\end{array}$ & $\begin{array}{c}\text { Relative humidity } \\
(\%)\end{array}$ & $\begin{array}{c}\text { Equilibrium } \\
\text { moisture } \\
\text { content }(\%)\end{array}$ \\
\hline 55 & 71 & 59 & 12 & 60 & 11.0 \\
50 & 71 & 59 & 12 & 60 & 11.0 \\
45 & 72 & 59 & 13 & 55 & 10.1 \\
30 & 72 & 59 & 13 & 55 & 10.1 \\
25 & 73 & 59 & 14 & 54 & 9.8 \\
20 & 73 & 59 & 14 & 54 & 9.8 \\
15 & 76 & 59 & 17 & 49 & 9.0 \\
$8 \pm 2$ & 76 & 59 & 17 & 49 & 9.0 \\
\hline
\end{tabular}


$T_{D}-T_{W D}+5=\frac{1.25}{U_{m}} \frac{\tan \beta}{\beta}+\frac{a^{\prime} \rho \gamma \beta^{2}}{\alpha . t_{1}} U_{m}$

Wet bulb temperature ( $\left.T_{\text {WD }}\right)$ was obtained using equation 2 .

$T_{W D}=33.4\left[1+k\left(1-\frac{\rho}{1000}\right)^{2}\right]$

Where $\rho$ is the basic density of wood, and $k$ is a constant. Also diffusivity (á) was calculated from equation 3.

$a^{\prime}=a_{1} \exp \left[a_{2}\left(1-\frac{\rho}{1000}\right)^{2}+\frac{T_{a}}{33.4}-1+\beta \times F\left(t_{1}\right) \times F\left(T_{a}\right)\right]$

Lumber surface heat mean $\left(T_{a}\right)$ was obtained from equation 4.

$T_{a}=T_{W D}+5\left[\frac{\frac{U m_{1}}{U m}-1}{\ln \frac{U m_{1}}{U m}}-1\right]$

The two constants ( $a_{1}$ and $a_{2}$ ) for hardwoods were equal to 7.3 and $0.24 \times 10^{-10}$, respectively. $\mathrm{F}\left(t_{1}\right)$ and $\mathrm{F}\left(T_{a}\right)$ were calculated by equations 5 and 6 , using MATLAB software.

$$
\begin{aligned}
& F\left(t_{1}\right)=\frac{1}{\sqrt{2 \pi}} \int_{-\infty}^{\frac{t_{1}}{0.02} \frac{0.02}{t_{1}}} e^{-y^{2} / 2} d y \\
& F\left(T_{a}\right)=\frac{1}{\sqrt{2 \pi}} \int_{-\infty}^{60-T_{a}} e^{-y^{2} / 2} d y
\end{aligned}
$$

Finally, intensity parameter $(\beta)$ was measured according to equation 7 .

$\frac{U m 1}{F . S . P}=\frac{\tan B}{B}$

Where, $\mu_{m 1}$ is critical moisture content when surface of lumber reaches to F.S.P.

Vessel properties. As to the importance of vessel properties in fluid transfer in hardwoods (Kurjatko et al. 2006, Taghiyari and Efhami 2011), three vessel features were measured in sapwood and heartwood, separately:

- Average vessel lumen area (AVLA);

- Percentage of vessel lumen area (PVLA), i.e. the total vessel lumen area / totally analyzed area $\times 100$;

- Vessel frequency (VF), i.e. vessel numbers in each $\mathrm{mm}^{2}$.

Although color differential between heartwood and sapwood of the studied paulownia was not severe, heartwood was cream colored and sapwood was distinctly lighter. Accordingly, the four or five outermost tree-rings were considered as sapwood and the rest as heartwood. However, the first three innermost rings were excluded because this part had a high fluctuation (Taghiyari and Efhami 2011). A pith to bark strip of about $1.5 \mathrm{~cm}$ wide and $1 \mathrm{~cm}$ thick was cut out of each board. After soaking in distilled water for two hours, the strips were divided into two parts from the border of sapwood/heartwood using a scalpel. Wood stripes were then sectioned using a sledge microtome to have a level and fresh surface. To increase the contrast between vessels and the ground tissue, a technique combining a black felt marker and white chalk was applied (Gärtner and Nievergelt 2010). The prepared stripes were scanned using a high resolution scanner (4,800 dpi). The resulting Images were transferred to Image J (v1.46, http://rsb.info.nih. gov/ij) and vessel features were analyzed in the total area of each section (sapwood and heartwood). Total analysis area for sapwood and heartwood of each stripe was around 1.6 and $7 \mathrm{~mm}^{2}$, respectively. Moreover, $15 \mu \mathrm{m}$ thick crosssections, cut from these stripes were double stained with $1 \%$ water soluble Safranin - Astrablue following conventional microscopic technique for wood studies (Schweingruber et al. 2006), and pictured under a stereomicroscope. Percentage of vessels with tyloses (PVT), i.e. the number of vessels containing tyloses / total number of vessels was calculated in these pictures. These microscopic sections as well as some extra radial and tangential sections were also studied under a light microscope to visually trace the severity of tyloses in vessels.

Gas permeability measurements. Longitudinal gas permeability measurement was carried out by an apparatus designed and built by the first author (figure 2) equipped with a 7-phase automatic time-measuring device with milli-second precision. Tangential permeability, as well as flow through parenchyma and fibers, is insignificant compared with longitudinal permeability in hardwoods (Siau 1971, 1984); therefore, in the present study, only longitudinal permeability was measured; however, further studies should be carried out to also investigate the effects of different drying schedules on permeability in tangential and radial directions. Permeability was determined with the intention to find out if other factors, such as drying schedules, could also influence gas permeability rather than density (Taghiyari 2013), vessel properties or perforation plates (Taghiyari 2012). Falling-water volume-displacement method was used to calculate specific longitudinal gas permeability values based on the microstructure porosity of wood (Siau 1995); the apparatus and the method can be used to measure gas permeability in porous media with pores from 5 to 1,000 microns in diameter. About 40 to 50 specimens were randomly cut at scattered locations from each board of each treatment by a hole-saw. Diameter of specimens was $17 \mathrm{~mm}$. For each specimen, gas permeability values were measured at 7 different water-column heights in a single run; that is, at 7 different vacuum pressures. Internal diameter of the glass tube was $13 \mathrm{~mm}$. Water level was $15 \mathrm{~cm}$ above the starting sensor of the first time-measurement device (Gas 1). Connection between the specimen and holder was made fully air-tight. A pressure gauge with milli-bar precision was connected to 


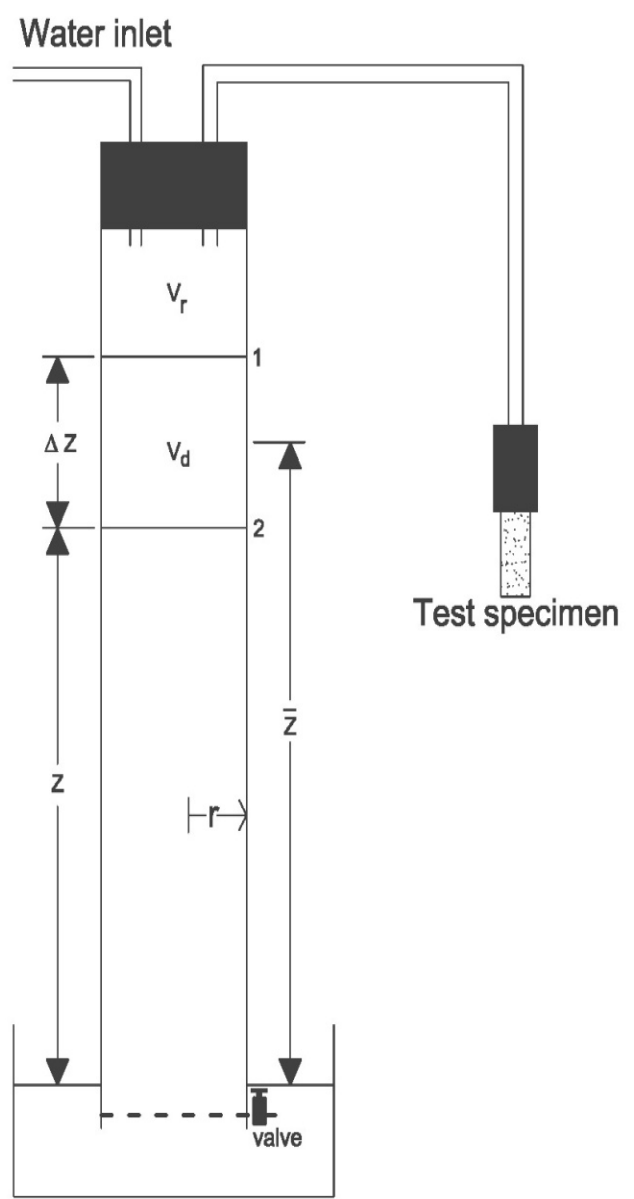

Figure. 2. Schematic overview of the gas permeability apparatus (USPTO No. US 8,079,249, B2) equipped with single-storey milli-second precision electronic time measurement device (Approved by The Iranian Research Organization for Scientific and Technology under certificate No. 47022).

Presentación esquemática del aparato de permeabilidad a los gases (USPTO No. US 8.079.249, B2), equipado con dispositivo electrónico de precisión de mili-segundos para medición del tiempo (aprobado por la Organización Iraní de Investigación para la Ciencia y Tecnología, certificado $\mathrm{N}^{\circ} 47022$ ).

the whole structure to monitor pressure gradient $(\Delta \mathrm{P})$ and vacuum pressure at any particular time as well as height of water column.

Two measurements were taken for each specimen (Taghiyari 2012). The superficial permeability coefficient was then calculated (equations 8 and 9). The superficial permeability coefficients were then multiplied by the viscosity of air ( $\left.\mu=1.81 \times 10^{-5} \mathrm{~Pa} \mathrm{~s}\right)$ for the calculation of the specific permeability $\left(K=k_{g} \mu\right)$.

$k_{g}=\frac{V_{d} C L\left(P_{\text {atm }}-0.074 \bar{z}\right)}{t A(0.074 z)\left(P_{\text {atm }}-0.037 z\right)} \times \frac{0.760 \mathrm{mHg}}{1.013 \times 10^{6} \mathrm{~Pa}}$

$C=1+\frac{\mathrm{V}_{\mathrm{r}}(0.074 \Delta \mathrm{z})}{\mathrm{V}_{\mathrm{d}}\left(\mathrm{P}_{\mathrm{atm}}-0.074 \mathrm{z}\right)}$
Where:

$k_{q}=$ longitudinal specific permeability $\left(\mathrm{m}^{3} \mathrm{~m}^{-1}\right)$

$V_{d}^{g}=\pi r^{2} \Delta z[\mathrm{r}=$ radius of measuring tube $(\mathrm{m})]\left(\mathrm{m}^{3}\right)$

$C=$ correction factor for gas expansion as a result of chan-

ge in static head and viscosity of water.

$L=$ length of wood specimen (m)

$P_{a t m}=$ atmospheric pressure (m Hg)

$\bar{Z}^{a t m}=$ average height of water over surface of reservoir during period of measurement $(\mathrm{m})$

$t=$ time $(s)$

$A=$ cross-sectional area of wood specimen $\left(\mathrm{m}^{2}\right)$

$\Delta z=$ change in height of water during time $\mathrm{t}(\mathrm{m})$

$V_{r}=$ total volume of apparatus above point 1 (including volume of hoses) $\left(\mathrm{m}^{3}\right)$

Liquid permeability measurement. Liquid permeability was measured using RILEM test method II.4 according to RILEM Commission 25, PEM, Test Method 1154 by International Union of Laboratories and Experts in Construction Materials, Systems, and Structures; penetration tests were conducted under laboratory conditions according to ASTM E-514. Laboratory conditions comprised air temperature of $24 \pm 3{ }^{\circ} \mathrm{C}$, and relative humidity of $45 \pm 4 \%$. Once the specific gas permeability was measured, the specimen was fixed at the end of the RILEM tube in a vertical position to measure longitudinal liquid permeability; the tube was then filled with distilled water. Water gradually entered the specimen. The time during which enough water passed through the specimen to form a drop, falling from the end

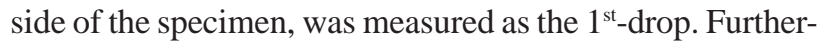
more, as the water of the RILEM tube gradually entered the specimen, the top surface of water in the tube gradually lowered. Once the water surface lowered by $50 \mathrm{~mm}$ (equal to $6.6 \mathrm{~cm}^{3}$ of water volume), another liquid permeability time was measured as the $50 \mathrm{~mm}$ lowering time. In the present study, the liquid times are only reported as an indicator of the speed of liquid flow through wood structure. Correlations between each of the 7 gas permeability times were separately calculated with the two liquid permeability times (1st-drop, and 50-mm lowering time).

Statistical analyses. Statistical analyses were conducted using a SAS software program, version 9.2 (2010). Oneway ANOVA was performed to discern significant differences at the $95 \%$ level of confidence. Grouping was then made between treatments, using the Duncan's test. Regression and hierarchical cluster analyses, including dendrogram and using Ward methods with squared Euclidean distance intervals, were carried out by SPSS/18 (2010). A cluster analysis was performed to find similarities and dissimilarities between treatments based on more than one property. Duncan's grouping is not capable of considering more than one property at a time to find the extent of similarities among different treatments; the cluster analysis can carry out a similarity test based on more than one property at a time, providing a better notion on treatments as a 
whole. In the present study, the cluster analysis was carried out based on the three fluid flow properties simultaneously, including the specific gas permeability, the liquid permeability of $1^{\text {st }}$-drop and the liquid permeability of $50-\mathrm{mm}$ lowering time. The scaled indicator in the cluster analysis shows how much similar or different treatments are; lower scale numbers show more similarities while higher ones show dissimilarities.

\section{RESULTS}

Results showed a significant difference among all vessel properties between sapwood and heartwood (table 4). Heartwood showed higher values for all vessel properties measured; that is, vessels were bigger, more frequent, and they covered a larger area in the heartwood, while tyloses were less common in sapwood. The average vessel lumen area (AVLA) in heartwood was $0.038\left(\mathrm{~mm}^{-2}\right)$, while in sapwood, it was 0.03 . The percentage vessel lumen area was $19 \%$ in the heartwood and vessel frequency was $5.1\left(\mathrm{~mm}^{-2}\right)$ in heartwood. Visual observation showed more tyloses along vessels in the heartwood (figure 3).

As to the permeability values, in order to be consistent with the previous studies on gas permeability in paulownia, Gas1 was used for reporting purposes (Ghorbani et al. 2012). The highest specific gas permeability was found in the sapwood of diffusion-2 (D-2) $\left(0.0027 \times 10^{-13} \mathrm{~m}^{3}\right.$ $\mathrm{m}^{-1}$ ); and the lowest was observed in the heartwood of D-1 $\left(0.0019 \times 10^{-13} \mathrm{~m}^{3} \mathrm{~m}^{-1}\right)$ (figure 4). Heartwood dried with all three initial MCs (under the three drying schedules) showed significantly lower gas permeability in comparison to the sapwood.

The lowest liquid time (that is, the highest liquid permeability value) was found in the sapwood specimens dried under schedule D-1 (1,102,320 seconds) (figure 5); and the highest liquid time (the lowest liquid permeability) was observed in the heartwood of D-3 $(1,373,400$ seconds). No significant difference was observed in the liquid permeability of sapwood and heartwood in any of the initial MCs.

Regression analyses between the specific gas permeability and liquid permeability in the three different drying schedules, both in the sap- and heartwood of paulownia wood, showed low insignificant R-squares (table 5).
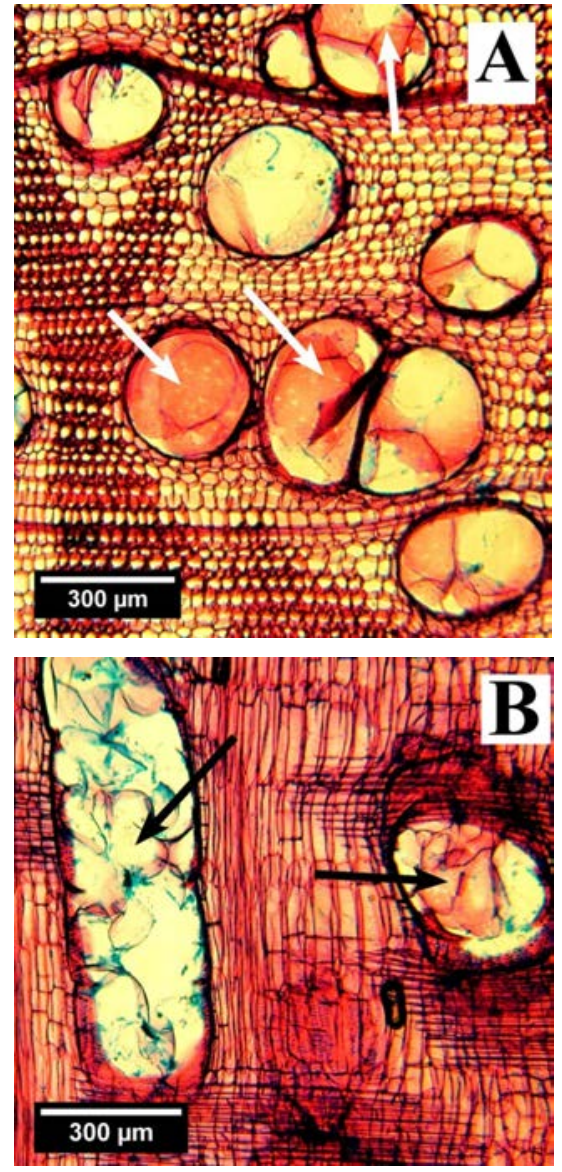

Figure. 3. Microscopic image showing tense tyloses that block the vessel elements; A. cross-sectional view, B. radial view. Imagen microscópica mostrando tilosis que bloquea los elementos del vaso; A) vista en sección transversal, B) vista radial.

Cluster analyses among the three diffusion schedules, based on both gas and liquid permeability time values, showed close clustering between sapwood and heartwood of the specimens dried under D-1 (figure 6A). Furthermore, a highly significant difference was observed between diffusion drying model of D-1 and the other two diffusion drying models with different initial MCs. As to the D-2 and D-3, sapwoods and heartwoods were clustered quite similarly; however, a significant difference was observed between the

Table 4. Vessel properties in the sapwood and heartwood. Propiedades de los vasos en la albura y el duramen.

\begin{tabular}{lcc}
\hline \multicolumn{1}{c}{ Vessel properties } & Sapwood & Heartwood \\
\hline Average vessel lumen area $\left(\mathrm{mm}^{2}\right)$ & $0.030(0.0024)$ & $0.038(0.0028)$ \\
Vessel area (\%) & $11.2(1.4)$ & $19(1.6)$ \\
Vessel frequency $\left(\mathrm{mm}^{-2}\right)$ & $3.8(0.29)$ & $5.1(0.34)$ \\
Vessels with tyloses (\%) & $48(6.6)$ & $74(10.1)$ \\
\hline
\end{tabular}

* Figures in parenthesis are the standard deviations. 


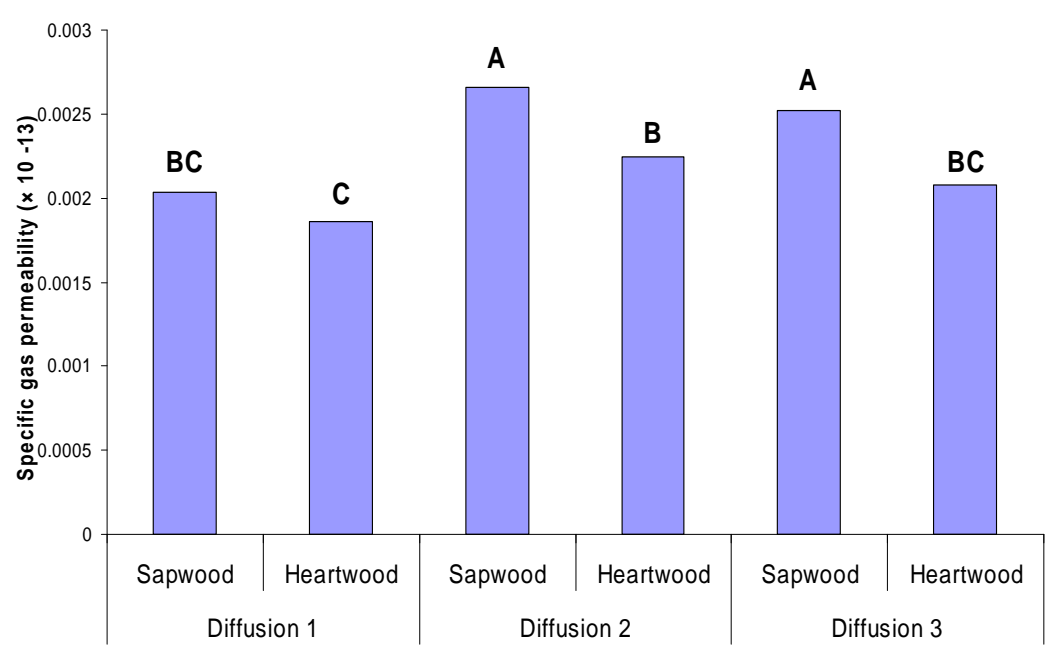

Figure. 4. Specific gas permeability values (Gas 1) of paulownia sapwood and heartwood dried using diffusion drying schedule $\left(\times 10^{-13} \mathrm{~m}^{3} \mathrm{~m}^{-1}\right)$ (Letters on each column are the Duncan's groupings).

Valores de permeabilidad específica de gas (Gas 1) de la albura y el duramen de paulonia secados con programas de secado de difusión $\left(\times 10^{-13} \mathrm{~m}^{3} \mathrm{~m}^{-1)}\right.$ (letras sobre cada columna son agrupaciones de Duncan).

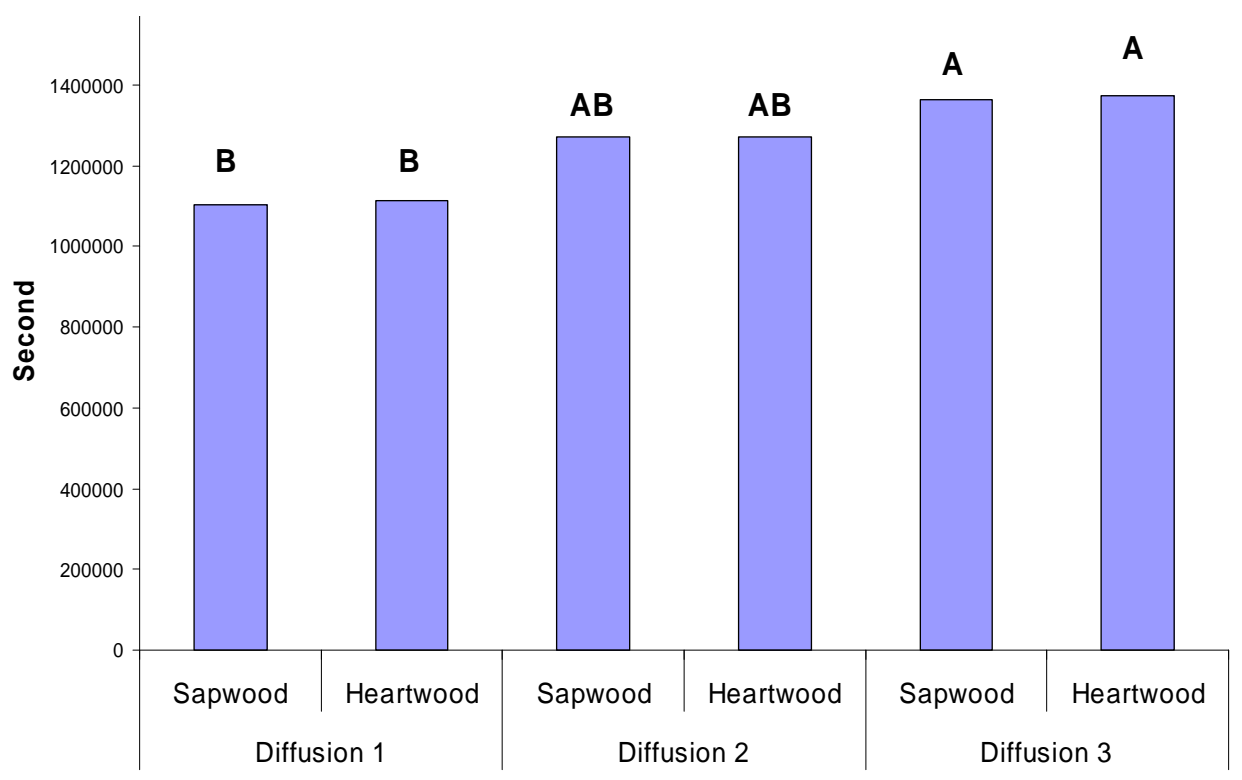

Figure. 5. Liquid permeability of 50-mm-lowering time (s) for the sapwood and heartwood of paulownia wood dried using three diffusion drying schedules ( $\mathrm{D}$ = diffusion) (letters on each column are the Duncan's groupings).

Permeabilidad a los líquidos de menor tiempo (s), de madera de $50 \mathrm{~mm}$ para albura y duramen de paulonia secada utilizando tres programas de secado de difusión ( $\mathrm{D}$ = difusión) (letras en cada columna son agrupaciones de Duncan).

Table 5. Regression analyses between the specific gas permeability and liquid permeability in the three different diffusion drying schedules in the sapwood and heartwood of paulownia wood.

Análisis de regresión entre la permeabilidad específica al gas y permeabilidad a los líquidos en los tres programas de secado de difusión en la albura y el duramen de la madera de paulonia.

\begin{tabular}{lcccccc}
\hline Correlation between gas and & \multicolumn{2}{c}{ Diffusion 1} & \multicolumn{2}{c}{ Diffusion 2} & \multicolumn{2}{c}{ Diffusion 3} \\
\cline { 2 - 7 } liquid permeability & Sap & Heart & Sap & Heart & Sap & Heart \\
\hline $\mathrm{R}^{2}$ values & 0.08 NS (-) & 0.02 NS (-) & 0.46 NS (-) & 0.60 NS (-) & 0.17 NS (-) & 0.34 NS (-) \\
\hline
\end{tabular}

NS = Non significant correlation. (-) Negative correlation. 


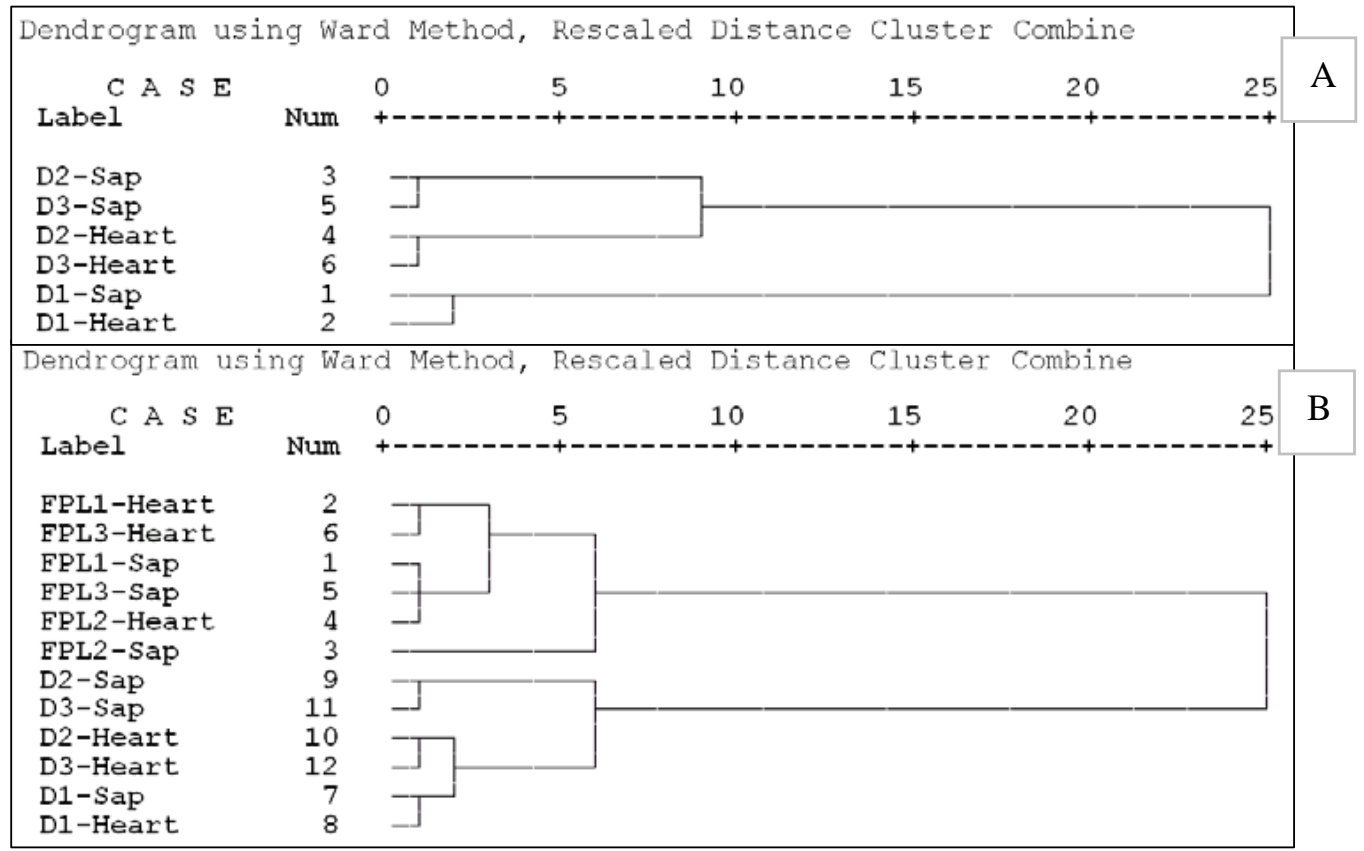

Figure. 6. Cluster analyses of the three (A) and six (B) drying schedules in the sapwood and heartwood based on specific gas permeability values and times as well as liquid permeability time ( $\mathrm{D}=$ diffusion; Sap = sapwood; Heart = heartwood).

Análisis de grupos de los tres (A) y seis (B) programas de secado en la albura y el duramen basados en valores y tiempos de permeabilidad específica a los gases, así como tiempo de permeabilidad a los líquidos $(\mathrm{D}=$ difusión; Sap = albura; Heart = duramen).

two sapwoods and the two heartwoods. Cluster analyses of the three diffusion schedules in the present study along with the three FPL schedules in the previous study (Taghiyari et al. 2014) showed significantly different clustering of the two groups of schedules, namely FPL and diffusion (figure 6B).

\section{DISCUSSION}

Previous studies on the effect of vessel properties on permeability reported the positive effect of vessel size and frequency on permeability in different species (Kurjatko et al. 2006, Silva et al. 2010). Therefore, based on the higher values of vessel features for heartwood section in the present study in comparison to the sapwood, heartwood was expected to be more permeable. However, as it was reported in the results section, permeability in heartwood was lower than it was in sapwood in all three drying schedules. In this regard, the intense tyloses formed in the heartwood acted as a physical barrier towards flow of fluid, resulting in a significant lower permeability. The intense tyloses also made density in the heartwood section to be more in value than in sapwood, although not significantly different; $0.316 \mathrm{~g} \mathrm{~cm}^{-3}$ in heartwood in comparison to $0.303 \mathrm{~g} \mathrm{~cm}^{-3}$ in sapwood. Similar significant decrease in permeability due to the occurrence of tyloses was reported in beech wood (Shahverdi et al. 2013). This clearly proved the high impact of tyloses on fluid flow in solid woods; that is, tyloses acted as an impermeable physical barrier towards fluids, decreasing permeability, although vessel properties showed higher values in heartwood (table 4).

A previous study on the specific gas permeability of paulownia wood, however, reported specific gas permeability to be $6.75\left(\times 10^{-13} \mathrm{~m}^{3} \mathrm{~m}^{-1}\right)$ (Ghorbani et al. 2012); however, they reported the age of the trees to be under 10 years old. It is then concluded that the age of trees, together with the formation of tyloses in vessel elements, significantly influences fluid flow in paulownia wood. Furthermore, similar paulownia boards, as in the present study, dried under three FPL drying schedules showed significantly higher permeability (Taghiyari et al. 2014). It can therefore be concluded that different initial MCs and drying schedules, and the way they may alter the water-vapor diffusion in the wood structure, not only significantly affect tyloses and the porous structure, but also the formation of micro-cracks as well (Dashti et al. 2012, Shahverdi et al. 2012b), resulting in significant differences in gas permeability.

Previous studies reported negative high correlation between gas and liquid permeability in all solid woods without tyloses; however, in the present study low insignificant correlations were found. Similar low insignificant correlation was also reported for paulownia wood dried under three FPL schedules (Taghiyari et al. 2014). It can then be concluded that the formation of tyloses significantly alters the behavior of solid woods towards the 
transfer of gas and liquid fluids; that is, lack of tyloses makes gas and liquid permeability behave more similarly than when tyloses are formed in vessels, blocking the fluid flow as an impermeable physical barrier.

Based on the close clustering between sapwood and heartwood of the specimens dried under D-1, it can be concluded that in higher initial MC, no significant difference would occur in the fluid flow behavior in paulownia wood. Furthermore, the highly significant difference between D-1 with the other two initial MCs showed noteworthy effects caused by the initial MC on gas and liquid permeability of the dried boards. As to the close clustering of sapwoods and heartwoods of D-2 and D-3, it can be concluded that initial MCs of 75.5 and 53.5 similarly affect gas and liquid permeability in paulownia wood.

The highly considerable clustering of the three diffusion schedules in the present study, along with the three FPL schedules in the previous study (Taghiyari et al. 2014), clearly proved that different schedules can significantly affect fluid flow in paulownia wood. As there was no significant difference in the vessel properties of different schedules, neither in the present study, nor in the previous study, it can also be concluded that drying schedules alter the tyloses structure in a way that appreciably influences the gas and liquid permeability in the porous media. However, more studies on the specific effects of drying schedules on tyloses structures should be carried out to come to a final conclusion on the nature of these effects.

Drying schedules were reported to affect solid woods in three ways: the direct effect of moisture loss, the internal drying strain and stresses as well as occurrence of checks and cracks, and the direct influence of temperature on wood components (Keey et al. 2000, Thiam et al. 2002). The present study proved that different initial MCs and drying schedules also significantly affect the process of fluid flows, both in gas and liquid forms, affecting further drying properties of solid woods as well as their final applications.

D-3 was reported to have the lowest drying defects, the lowest warping, and the most homogeneous moisture profile (Miri Tari and Madhoushi 2013); moreover, the present study showed that D-3 had the lowest liquid permeability. D-1 showed the highest liquid permeability. Therefore, it can be concluded that choosing the initial MC for the stacks to be dried under diffusion drying schedules would greatly be dependent on the final application; that is, if the boards are to be impregnated with preservatives or fire-retardants, D-1 would be recommended. If, however, the quality of the dried boards is to be of the outmost importance, D-3 would be more recommendable. Based on the results obtained from this research project, it can be concluded that different initial MCs may significantly influence diffusion as well as wood structure. However, more studies on diffusion values of Paulownia wood dried under different drying schedules should be carried out to come to a final conclusion as to how it can be affected.
As to the low thermal conductivity coefficient of wood, the authors are working on utilizing high thermal conductivity of metal nanoparticles (Sadeghi and Rastgo 2012, Wang et al. 2013) in order to decrease thermal gradient in lumber and therefore to accelerate the process of wood drying with the lowest drying defects possible.

\section{CONCLUSIONS}

Gas and liquid permeability values, as two main properties describing the fluid flow in porous media, were measured in paulownia wood dried under diffusion drying schedules with three different initial moisture contents. It was concluded that gas permeability was significantly dependent on both the initial MC and location of the specimens in trees (being from the sapwood or heartwood portion of tree). However, liquid permeability was only dependent on the initial MC of the boards when dried under diffusion drying schedules; that is, sap- and heartwood did not significantly affect the liquid permeability. Paulownia timber with the higher initial moisture content of under $60 \%$ (D-1) is recommended to the impregnation industry as timber dried under this initial MC showed the highest liquid permeability, essentially needed in wood preservation and impregnation industry. Moreover, formation of tyloses significantly decreases permeability. In fact, tyloses play a more important role in permeability than do vessel size and frequency, acting as an impermeable barrier, eventually decreasing permeability.

\section{ACKNOWLEDGMENTS}

The authors are grateful to Engr. Younes Sarvari Samadi, expert in fluid flow in porous media for his great help in analyzing and interpretation of the results.

\section{REFERENCES}

Ashouri A, Gh Ebrahimi. 1999. Establishing kiln drying schedule for oak Lumber. Journal of Agricultural Science and Natural Resources 3: 31-37.

Babiak M. 2007. Sorption isotherms of wood. In Perre P ed. Fundamentals of wood dryings. Nancy, France. A.R.BO.LOR, ISBN 9782907086127.

Chaiyo K, P Rattanadecho. 2013. Numerical Analysis of HeatMass Transport and Pressure Build-Up in 1D Unsaturated Porous Medium Subjected to a Combined Microwave and Vacuum System. Drying Technology 31(6): 684-697. DOI: 10.1080/07373937.2012.754461.

Danvind J, Ekevad M. 2006. Local water vapor diffusion coefficient when drying Norway spruce sapwood. Journal of Wood Science DOI 10.1007/s10086-005-0753-4.

da Silva WP, L Duarte da Silva, CMDPS e Silva, PL Nascimento. 2011. Optimization and simulation of drying processes using diffusion models: application to wood drying using forced air at low temperature. Wood Science and Technology 45(4): 787-800.

Dashti H, A Tarmian, M Faezipour, M Shahverdi. 2012. Effect 
of microwave radiation and pre-steaming treatments on the conventional drying characteristics of fir wood (Abies alba L.). Lignocellulose 1(3): 166-173.

Figueroa M, C Bustos, P Dechent, L Reyes, A Cloutier, M Giuliano. 2012. Analysis of rheological and thermo-hygro-mechanical behaviour of stress-laminated timber bridge deck in variable environmental conditions. Maderas. Ciencia y tecnologia 14(3): 303-319.

Gärtner H, D Nievergelt. 2010. The core-microtome: A new tool for surface preparation on cores and time series analysis of varying cell parameters. Dendrochronologia 28: 85-92.

Ghorbani M, M Akhtari, HR Taghiyari, A Kalantari. 2012. Effects of silver and zinc-oxide nanoparticles on gas and liquid permeability of heat-treated Paulownia wood. Austrian Journal of Forest Science 129(2): 106-123.

Keey RB, Langrish TAG, Walker JCF. 2000. Kiln-Drying of Lumber. Springer Series in Wood Science ISBN: 978-3642-64071-1. $337 \mathrm{p}$.

Korkut S, B Guller. 2007. Comparison of two drying schedules for European Hophornbeam (Ostrya carpinifolia Scop.) lumber. Drying Technology 25(12): 1977-1984.

Kurjatko S, M Mamoňová, M Babiak, J Hudec. 2006. Permeability of ash and elm wood for water. In: Wood structure and properties '06. Zvolen, Slovakia. Stanislav Kurjatko, Jozef Kúdela, Rastislav Lagaňa eds. Arbora Publishers p. 281-287

Malmquist L. 1991. Lumber drying as a diffusion process. Holz als Roh - und Werkstoff 49: 161-167.

Miri Tari SM, M Madhoushi. 2013. Kiln drying schedule based on diffusion theory. World of Sciences Journal 1-special issue $9-24$.

Mosqueda MRP, LG Tabil, C Christensen. 2013. Effect of Drying Conditions and Level of Condensed Distillers Solubles on Protein Quality of What Distillers Dried Grain With Solubles. Drying Technology 31(7) DOI: 10.1080/07373937.2013.765446.

Oltean L, A Teischinger, C Hansmann. 2007. Influence of temperature on cracking and mechanical properties of wood during wood drying - A review. BioResources 2(4): 789-811.

Rafiei F, Gh Ebrahimi. 2007. Adjustment of kiln drying conditions for hornbeam (Carpinus betulus L.) wood of $7.5 \mathrm{~cm}$ thickness. Journal of the Iranian Natural Resources 60(2): 607-616.

Ruprecht H, H Vacik, H Steiner, G Frank. 2012. ELENA - a methodological approach for the long term monitoring of the natural regeneration of natural forest reserves dominated by Norway-spruce (Vaccinio-Piceetea). Austrian Journal of Forest Science 129(2): 67-105.

Sadeghi B, S Rastgo. 2012. Study of the shape controlling silver nanoplates by reduction process. International Journal of Bio-Inorganic Hybrid Nanomaterials 1(1): 33-36.

Shahverdi M, H Dashti, MA Hossein. 2012a. Establishing a Kiln
Drying Schedule for Poplar (populus alba) lumber of $7 \mathrm{~cm}$ thickness. BioResources 7(1): 26-37.

Shahverdi M, A Tarmian, H Dashti, Gh Ebrahimi, M Tajvidi. 2012b. Mechanical properties of poplar wood (Populus alba) dried by three kiln drying schedules. BioResources 7(1): 1092-1099.

Shahverdi M, H Dashti, HR Taghiyari, S Heshmati, H Gholamiyan, MA Hossein. 2013. The impact of red heartwood on drying characteristics and mass transfer coefficients in beech wood. Austrian Journal of Forest Science 130(2): 85-101.

Schweingruber FH, A Börner, ED Schulze. 2006. Atlas of woody plant stems. Evolution, structure, and environmental modifications. Berlin, Germany. Springer-Verlag. 229 p.

Siau JF. 1971. Flow in Wood. New York, USA. Syracuse University Press. Standard book No: 8156-5028-0, Catalog Card No: 70-155829; p. 131.

Siau JF. 1984. Transport processes in wood. New York, USA. Springer-Verlag. 245 p.

Siau JF. 1995. Wood: Influence of moisture on physical properties. Blacksburg, VA, USA. Department of Wood Science and Forest Products Virginian Polytechnic Institute and State University. p. 1-63.

Silva MR, GO Machado, J Deiner, C Calil. 2010. Permeability measuremens of brazilian eucalyptus. Material Research 13(3): 281-286.

Simpson WT. 1991. Dry Kiln Operator's Manual. Madison, Wisconsin, USA. USDA Forest Service, Agriculture Handbook 188. $23 \mathrm{p}$.

Taghiyari HR, D Efhami. 2011. Diameter increment response of Populus nigra var. betulifolia induced by alfalfa. Austrian Journal of Forest Science 128 (2): 113-127.

Taghiyari HR. 2012. Correlation between gas and liquid permeabilities in some nanosilver-impregnated and untreated hardwoods. Journal of Tropical Forest Science 24(2): 249255.

Taghiyari HR. 2013. Effects of heat-treatment on permeability of untreated and nanosilver-impregnated native hardwoods. Maderas. Ciencia y Tecnologia 15(2): 183-194. DOI 10.4067/S0718-221X20130005000015.

Taghiyari HR, S Habibzadeh, SM Miri Tari. 2014. Effects of wood drying schedules on fluid flow in Paulownia wood. Drying Technology 32: 89-95. DOI 10.1080/07373937.2013.813855.

Thiam M, MR Milota, R Leichti. 2002. Effect of high-temperature drying on bending and shear strengths of western hemlock lumber. Forest Products Journal 52(4): 64-68.

Wang H, Q Ma, H Niu, X Mao, L Wan, J Xu, S Miao. 2013. Hydrothermal growth of aligned $\mathrm{ZnO}$ nanorods along the seeds prepared by magnetron sputtering and its applications in quantum dots sensitized photovoltaic cells. Journal of Nanomaterials and Molecular Nanotechnology 2:2 dx.doi. org/10.4172/2324-8777.1000108. 